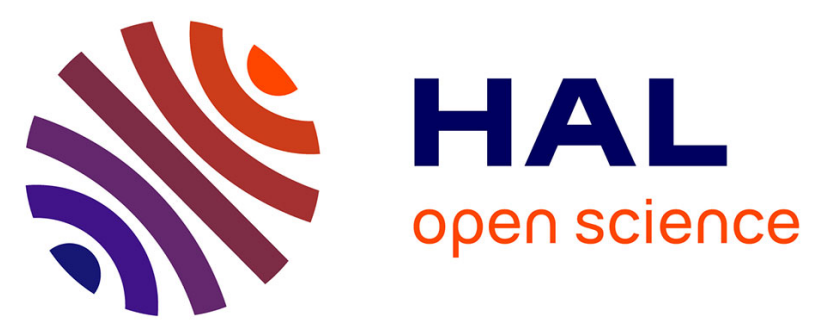

\title{
Response of understorey plant communities and traits to past land use and coniferous plantation
}

\author{
L. Bergès, Thomas Feiss, Catherine Avon, Hilaire Martin, Xavier Rochel, \\ Emmanuelle Dauffy-Richard, Thomas Cordonnier, Jean-Luc Dupouey
}

\section{- To cite this version:}

L. Bergès, Thomas Feiss, Catherine Avon, Hilaire Martin, Xavier Rochel, et al.. Response of understorey plant communities and traits to past land use and coniferous plantation. Applied Vegetation Science, 2017, 20 (3), pp.468-481. 10.1111/avsc.12296 . hal-01592226

\author{
HAL Id: hal-01592226 \\ https://hal.science/hal-01592226
}

Submitted on 16 May 2020

HAL is a multi-disciplinary open access archive for the deposit and dissemination of scientific research documents, whether they are published or not. The documents may come from teaching and research institutions in France or abroad, or from public or private research centers.
L'archive ouverte pluridisciplinaire HAL, est destinée au dépôt et à la diffusion de documents scientifiques de niveau recherche, publiés ou non, émanant des établissements d'enseignement et de recherche français ou étrangers, des laboratoires publics ou privés.

\section{다(1)(2)}

Distributed under a Creative Commons Attribution - ShareAlikel 4.0 International 


\section{Response of understory plant communities and traits to past land}

\section{2 use and coniferous plantation}

3

4 Laurent Bergès, Thomas Feiss, Catherine Avon, Hilaire Martin, Xavier Rochel, Emmanuelle

5 Dauffy-Richard, Thomas Cordonnier, Jean-Luc Dupouey

6

7 Laurent Bergès (corr. author, laurent.berges@ irstea.fr): Irstea, UR EMGR, 2 rue de la Papeterie-BP 76,

8 Saint-Martin d'Hères, F-38402, France. Univ. Grenoble Alpes, F-38402 Grenoble, France

9 Thomas Feiss (thomas.feiss@gmail.com): Chercheur indépendant, 157 rue Pasteur, F-88500 Mirecourt,

10 France

11 Catherine Avon (catherine.avon@hotmail.fr): Semperfloris, F-07000 Privas

12 Hilaire Martin (hilaire.martin@irstea.fr), Emmanuelle Dauffy-Richard: Irstea, UR EFNO, Domaine des

13 Barres, F-45290 Nogent-sur-Vernisson, France

14 Xavier Rochel (xavier.rochel@univ-lorraine.fr): Université de Lorraine, Campus Lettres et Sciences

15 Humaines, 23 boulevard Albert $1^{\mathrm{er}}$, BP 13397, F-54015 NANCY France

16 Thomas Cordonnier (thomas.cordonnier@irstea.fr): Irstea, UR EMGR, 2 rue de la Papeterie, BP 76,

17 Saint-Martin-d'Hères, F-38402, France. Univ. Grenoble Alpes, F-38402 Grenoble, France.

18 Jean-Luc Dupouey (dupouey@nancy.inra.fr): INRA-Nancy University, UMR 1137 Forest Ecology and

19 Ecophysiology, F-54280 Champenoux, France 


\section{Abstract}

Questions: How did past land use and conifer plantation affect understory plant communities? What plant traits explain understory vegetation response to agricultural past land use and coniferous plantation?

Location: Forest of Orléans (50 000 ha), Loiret, northern central France.

Methods: Canopy cover, herb layer composition, litter and soil properties were measured in $80100 \mathrm{~m}^{2}$ plots sampled in plantations of Pinus sylvestris or P. nigra vs. natural regenerations of Quercus petraea and $Q$. robur along a gradient of forest continuity (using historical maps and aerial photos from 1840, 1949 and 2006). We related 15 plant traits to past land use and tree species using RLQ and fourth-corner analyses.

Results: The magnitude of past land use effect largely exceeded that of coniferous plantation. Postagricultural forests, even 150 years after afforestation, differed from ancient forests in soil properties (thinner humus layer, higher phosphorus content, higher $\mathrm{pH}$ and lower $\mathrm{C} / \mathrm{N}$ ratio) and plant traits. Ancient forests hosted more forest core species, stress-tolerant, competitive species and bryophytes, but fewer ruderals, annuals/biennials, shrubs and trees and nutrient-demanding species, and had lower specific leaf area and higher leaf dry matter content. Conifer plantations had a thicker humus layer, lower $\mathrm{pH}$ and higher $\mathrm{C} / \mathrm{N}$ ratio than deciduous forests, and hosted more light-demanding species but less forest core species. Importantly, differences in soil and plant traits between conifer plantations and naturally regenerated deciduous stands were discernible in both recent and ancient forests, indicating that tree species lastingly influence ecosystem functioning.

Conclusions: Past land use and coniferous plantation resulted in different understory plant communities and traits under pine plantations and naturally regenerated oak stands. These differences were driven by soil acidification, litter decomposition rate, light conditions, canopy development, soil disturbance, stand management, and dispersal and recruitment limitations. Coniferous plantations slowed down the recovery of post-agricultural forests to ancient deciduous forest conditions. Applying natural regeneration and favouring native deciduous tree species thus helps recreate or maintain ancient forest plant communities.

Keywords: ancient forest, coniferous plantation, functional trait, land use history, tree species substitution, restoration.

Nomenclature: French BDTFX flora nomenclature and European BDNBE bryophyte nomenclature (http://www.tela-botanica.org). 
Author-produced version of the article published in Applied Vegetation Science, 2017, 20, 468-481.

The original publication is available at http://onlinelibrary.wiley.com

DOI: 10.1111/avsc.12296

\section{Introduction}

Two major changes have occurred in European forest landscapes over the last 250 years. First, forest cover has globally increased in many European countries since the Industrial Revolution (Mather et al. 1999) due to rural exodus and agricultural land set-aside (Cramer et al. 2008). In France and several other European countries, many former agricultural lowlands have been planted with Pinus and Picea species (see http://inventaire-forestier.ign.fr/spip/spip.php?rubrique80 and Leuschner et al. (2013). Second, large areas of deciduous forests have been converted to coniferous forests in western and central Europe since the beginning of the $20^{\text {th }}$ century, to develop more profitable industrial forestry (Wulf \& Heinken 2008). There is still intense debate on whether plantation forests help to maintain biodiversity or instead degrade it (Bremer \& Farley 2010). Some authors consider that plantations can accelerate the regeneration of native understory species and thus help conserve biodiversity (BoothroydRoberts et al. 2013), while others have shown no effect or a decrease in the number or the diversity of forest species (Aubin et al. 2008; Tullus et al. 2013). The value of plantations for biodiversity actually depends on several factors that are not always easy to disentangle: (i) tree species identity (ii) the nature of the earlier land cover (iii) proximity to native vegetation source, (iv) plantation silviculture and (v) soil conditions.

The role of tree species on understory plant communities is largely documented (Barbier et al. 2008). The overstory directly affects the understory through its impact on light availability (Wulf \& Naaf 2009) and by competition for water and nutrients (Barbier et al. 2009), especially on acidic sites (Härdtle et al. 2003). Canopy composition also indirectly affects understory through litter quality and decomposability (Hagen-Thorn et al. 2004), which influences topsoil nutrient availability and acidity (Augusto et al. 2015), the soil fauna (Reich et al. 2005) and the recruitment and growing conditions of seeds (Baeten et al. 2009a). Understory plant composition differs between coniferous and deciduous stands and can depend on the deciduous tree species being compared (Barbier et al. 2008).

Past land use lastingly influences forest soil properties and understory vegetation, which gave rise to the concept of ancient forest (AF) and ancient forest species (AFS) (Hermy \& Verheyen 2007). Forest soils on former arable fields are mostly differentiated from ancient forest by higher soil $\mathrm{pH}$ and phosphorus content, and lower nitrogen and carbon content (Sciama et al. 2009; De Schrijver et al. 2012). The association between forest continuity and ancient forest species is mainly related to their low dispersal capacity and low recruitment success in post-agricultural forests (Hermy \& Verheyen 2007); recruitment of ancient forest species in post-agricultural forests is partly determined by interspecific competition, soil characteristics and light availability (Baeten et al. 2009b). Understory-overstory relationships have generally been investigated without considering past land use (Barbier et al. 2008; Kooijman 2010). Although several studies on land use legacies have investigated the influence of tree species or regeneration mode (Aubin et al. 2008; Tullus et al. 2013; Thomaes et al. 2014), these have several limitations: (i) they did not include ancient forests as a control in their 
Author-produced version of the article published in Applied Vegetation Science, 2017, 20, 468-481.

The original publication is available at http://onlinelibrary.wiley.com

DOI: 10.1111/avsc.12296

sampling design, (ii) they explored a very short gradient of age since afforestation ( $<40$ years) and (iii) they rarely compared deciduous and coniferous species. To our knowledge, only one study investigated the two gradients (Wulf \& Heinken 2008) and found that deciduous stands did not guarantee higher richness of forest specialists, and underlined the role of former land use on the colonisation of forest species. There is still a need to explore the combined effects of past land use and tree species in more detail (Thomaes et al. 2012), in particular how conifer introduction can influence the recovery rate of understory plant communities to ancient forest conditions, using ancient coniferous forests as a control. Our aim was to investigate to what extent conifer plantations modified the composition and the traits of understory plant communities in recent and ancient forests compared with similar sites with deciduous tree species, addressing the three following questions:

(1) How did past land use and tree species affect understory plant communities and their traits and which of the two drivers was more influential?

(2) How did understory plant succession differ between conifers and deciduous forests in postagricultural stands?

(3) What plant traits (ecological performance, resource requirement, persistence, regeneration, or dispersion traits) explain understory plant response to past land use and conifer plantation?

We assumed that understory communities were close in deciduous and coniferous post-agricultural forests then diverged with increasing time since afforestation, due to several ecological filters: soil acidification and litter accumulation, more pronounced in coniferous stands (Augusto et al. 2015), subcanopy layer development, greater and faster in naturally regenerated deciduous stands, canopy cover conditions, more open in pine forests (Augusto et al. 2003) and soil disturbance, more frequent in plantations (Boch et al. 2013). We expected traits related to ecological performance, resource requirement, persistence, regeneration and dispersion were linked to forest continuity (Verheyen et al. 2003), and traits related to ecological performance, resource requirement and regeneration were associated with tree species (Barbier et al. 2008), but which of the two gradients was more influential on plant communities and traits was difficult to predict. Following Wulf and Heiken (2008), we also hypothesised that migration of forest core species [sensu Pellissier et al. (2013)] into recent coniferous forests would be delayed compared with deciduous forests, due to both dispersal and recruitment limitations.

\section{Methods}

\section{Study area, land use and forest management history}

The study was conducted in the Forest of Orléans $\left(48^{\circ} 00^{\prime} 28^{\prime \prime} \mathrm{N}, 2^{\circ} 09^{\prime} 39^{\prime \prime} \mathrm{E}\right)$, which contains a central block of ancient forest covering about 35,000 ha (Fig. 1). Elevation ranges from 107 to $174 \mathrm{~m}$, climate is oceanic, and mean annual precipitation is about $700 \mathrm{~mm}$. The study area was dominated by oak $(Q$. 
petraea and $Q$. robur), pine (Pinus nigra subsp. laricio var. corsicana and P. sylvestris) and mixed oakpine forests.

127 Forest cover reconstruction was based on two sources: historical maps of 1840 (Etat-Major map) and aerial photographs taken in 1949. Forest patches in 1840 were vectorised following a precise protocol (Favre et al. 2013) and then georeferenced with ArcGIS version 10.0 using about one reference point per $\mathrm{km}^{2}$. Land use in 1949 was checked on aerial photos. Current forest cover maps dating from 2006 were provided by the French National Forest Inventory (www.inventaire-forestier.ign.fr). Three forest age classes were defined in current forests: ancient forests (AF) (patches present in 1840, 1949 and 2006), intermediate-age forests (IF) (patches absent in 1840, present in 1949 and 2006), and recent forests (RF) (patches absent in 1840 and 1949, present in 2006). In the following, the term "postagricultural forests" includes intermediate-age forests and recent forests.

These maps and other documents on State forest management history showed that the study area had undergone two major changes in land use and forest management since the beginning of the $19^{\text {th }}$ century. First, a 23\% net increase in forest area occurred between 1840 (59,300 ha) and 2006 (73,200 ha), the resultant of a gain (21,700 ha) and a loss (-7,800 ha), ancient forest thus covering 51,500 ha (Fig. 1). Second, conifers were extensively planted on former agricultural lands but also on former deciduous forests. Conifers currently represent $40 \%$ of forest cover, compared with $6 \%$ of the total in 1870, and were absent in 1840. For historical reasons, we cannot separate the effects of regeneration mode from the effect of overstory composition, because Corsican and Scotch pines were planted, whereas most of the time sessile and pedunculate oaks were naturally regenerated.

\section{Sampling design}

We selected 80 sampling points crossing two types of dominant tree species composition (TSC): coniferous, mainly P. sylvestris and Pinus nigra subsp. laricio var. corsicana, noted CON vs. deciduous, mainly Quercus petraea - Q. robur, noted DEC; and the three classes of forest temporal continuity (FTC): ancient, intermediate-age and recent forests (Table 1). To reduce stand variability, we selected forest stands that were between 40 and 100 years old and only considered "pure stands" with more than $70 \%$ of the total basal area of either coniferous or deciduous species.

\section{Floristic survey, humus form and soil data collection}

154 At each of the 80 sampling points, the presence of understory vascular species (pteridophytes and 155 phanerogams) and terricolous bryophytes below $2 \mathrm{~m}$ in height were recorded in one $10 \times 10 \mathrm{~m}$ plot 156 between June 9 and July 22, 2011. The vegetation belongs to the phytosociological sub-alliance of 157 Quercenion robori-petraeae Rivas Mart. 1975. We also measured canopy cover of different strata and 158 humus form, and analysed soil samples to measure $\mathrm{pH} \mathrm{H}_{2} \mathrm{O}$, organic carbon content $\left(\mathrm{C}_{\text {org }}\right)$, total nitrogen content ( $\mathrm{N}$ content), potentially available phosphorus content and other soil parameters at two depths ( 0 - 
$5 \mathrm{~cm}$ and 15-20 cm). Appendix S1 gives a detailed presentation of forest stand and soil data protocol. Soil types were cambisols, dystric cambisols, planosols, entic podzols and podzols (WRB 2015). Topsoil texture was mostly sand or loamy sand with a predominantly clay horizon (silty slay, sandy clay or clay) appearing between 30 and $70 \mathrm{~cm}$. Moderate waterlogging was observed between 24 and $68 \mathrm{~cm}$. $\mathrm{pH} \mathrm{H}_{2} \mathrm{O}$ ranged from 3.9 to 5.7 and humus form varied from mesomull to dysmoder according to the classification of Ponge et al. (2002).

\section{Plant traits}

We investigated plant traits that were previously related to forest understory succession after land abandonment (Hermy \& Verheyen 2007) and that could vary according to tree species (Barbier et al. 2008). We selected 15 species traits and ecological features, and classified them according to their ecological function (Table 2): ecological performance, resource requirement, persistence, regeneration and dispersal ability (Verheyen et al. 2003; Violle et al. 2007). Trait values were extracted from several databases (Catminat, Ecoplant, Ellenberg, LEDA, Bioflor and $\mathrm{D}^{3}$ ). Although plant features related to ecological performance are not functional traits, we use the term "plant traits" to simplify. Details on plant traits are provided in Appendix S2. Detailed hypotheses on the expected relationships between each trait and the two gradients we investigated are presented in Appendix S3.

\section{Data analyses}

\section{Soil and stand variations among sites}

178 Preliminary analyses checked for soil and stand variations among sites (Appendix S1). To reduce the number of predictors in our analyses, we selected a short list of five environmental variables that are recognised to vary with forest continuity and tree species and reflected nutrient richness, light availability and past disturbance regime (Thomaes et al. 2012): humus index (litter effect on understory plants), $\mathrm{pH} \mathrm{H}_{2} \mathrm{O}$ (nutrient balance between exchangeable $\mathrm{H} / \mathrm{Al}$ and exchangeable cations), phosphorus content (legacy of former agricultural use) and light conditions: lower and upper canopy cover (CC 2$8 \mathrm{~m}$ and $\mathrm{CC}>8 \mathrm{~m})$.

\section{Plant communities}

186 To test how plant community composition varied with forest continuity and tree species, we first applied canonical correspondence analysis to the L-table after Hellinger transformation with forest continuity and tree species as explanatory variables. We conducted permutation tests to analyse the effects of the two factors and their interaction using 9999 permutations. We then performed a pCCA using forest continuity and tree species as constraints and humus index, $\mathrm{pH} \mathrm{H}_{2} \mathrm{O}, \log \left(\mathrm{P}_{2} \mathrm{O}_{5}+1\right), \mathrm{CC} 2-8 \mathrm{~m}$ and $\mathrm{CC}>$ $8 \mathrm{~m}$ as conditions to test whether forest continuity and tree species effects persisted after controlling for resource gradient differences. We did not apply RLQ, a method to directly analyse trait-environment relationships (Kleyer et al. 2012), because this approach is not adapted to test the effect of a set of 
variables after controlling for the effect of covariates (Jamil et al. 2013). Between-class RLQ is available (Dray et al. 2014), but impossible to apply when one aims at removing the effect of several variables, whereas partial canonical correspondence analysis (pCCA) is suited for this purpose (Borcard et al. 1992).

\section{Plant traits}

To analyse how species traits were influenced by forest continuity and tree species and which of the two gradients had a greater influence, we adopted the analysis framework proposed by Dray et al. (2014): we used RLQ to obtain a graphical display and related values of projections and fourth-corner analysis (Legendre et al. 1997) for testing statistical relationships between traits and environmental variables. RLQ was used to provide a simultaneous ordination and analyse the joint structure of three tables: $R$ (environmental gradients: forest continuity, tree species, humus index, $\mathrm{pH} \mathrm{H}_{2} \mathrm{O}, \log \left(\mathrm{P}_{2} \mathrm{O}_{5}+1\right), \mathrm{CC} 2-8 \mathrm{~m}$ and $\mathrm{CC}>8 \mathrm{~m}$ ), $\mathrm{L}$ (plant presence data) and $\mathrm{Q}$ (species traits). A multivariate test using permutation method was applied to evaluate the global significance of the traitenvironment relationships [see (Dray et al. 2014) and Appendix S4]. Using permutation method, we also tested the links between RLQ axes and traits or environmental variables to interpret the main pattern of variation and correlation (Dray et al. 2014). As the L-table contained presence-absence data only, categorical trait variation reflected change in proportion of each trait category. Fourth-corner was lastly applied to test the significance of bivariate associations between each trait, or each trait category, and each environmental variable. The link was measured by a Pearson correlation coefficient for two quantitative variables (trait and environmental variable), by a Pearson $\mathrm{Chi}^{2}$ and $\mathrm{G}$ statistic for two qualitative variables and by a Pseudo-F and Pearson $r$ for one quantitative variable and one qualitative variable. We used 9999 permutations in all randomization procedures, and the false discovery rate method (FDR) to adjust $P$ values for multiple testing. See Appendix S4 for more details on RLQ and fourth-corner analysis.

218 Finally, to test whether migration of forest core species [sensu Pellissier et al. (2013)] into recent coniferous forests would be delayed compared with deciduous forests, we ran a two-way ANOVA to test the effects of forest continuity, tree species composition and their interaction on the number of forest core species at plot scale.

\section{Results}

\section{Plant communities}


Author-produced version of the article published in Applied Vegetation Science, 2017, 20, 468-481.

The original publication is available at http://onlinelibrary.wiley.com

DOI: 10.1111/avsc.12296

The CCA applied to the floristic matrix composed of 80 sampling points and 197 species showed that $12.6 \%$ of the total variance was explained by forest continuity, tree species and their interaction. The projected inertias on the first three factorial axes were 43, 25 and 16\%, respectively. Permutation tests showed that the first two factorial axes and main effects were highly significant $(P<0.001)$ and the interaction was very significant $(P=0.004)$. Ancient, intermediate-age and recent forests were ordered along the first axis and the second, orthogonal axis discriminated between oak and pine stands (Fig. 2). Community dissimilarity between oak and pine was present along the forest continuity gradient but was much higher in recent compared to ancient forest. Plant turn-over from ancient to recent forest was slightly higher for pine. A partial CCA using forest continuity and tree species as constraints and humus index, $\mathrm{pH} \mathrm{H} \mathrm{H}_{2} \mathrm{O}, \log \left(\mathrm{P}_{2} \mathrm{O}_{5}+1\right), \mathrm{CC} 2-8 \mathrm{~m}$ and $\mathrm{CC}>8 \mathrm{~m}$ as conditions indicated that $8.5 \%$ of the total variance was explained by forest continuity and tree species, while the other environmental variables explained $14.0 \%$ of the total variance. Permutation tests showed that the main effects and interaction were still significant (forest continuity: $P=0.001$; tree species: $P=0.002$ and interaction: $P=0.02$ ). Individual plant species response to past land use and conifer plantation are presented in Appendices S5 and S6.

\section{Plant traits}

RLQ analysis showed that plant traits were significantly related to forest continuity, tree species and environmental variables (permutation tests for model 2 and model 4: $P<0.0001$, see Appendix S4 for description of models 2 and 4). The first two axes of the RLQ accounted for $95 \%$ of the total inertia ( $87 \%$ and $8 \%$ respectively). The variance of the environmental scores (R-table) was almost entirely preserved on the first two axes (98\%). The variance of the trait scores (Q-table) was also well preserved (40\% on the first axis and $58 \%$ on the first two axes).

The first ordination axis of the RLQ was associated with forest continuity and contrasted ancient forests (negative values) and recent forests (positive values), intermediate-age forests being roughly in the middle (Fig. 3a and Table 3). The second axis was related to tree species, and differentiated deciduous stands (positive values) from coniferous ones (negative values, Table 3). Humus index and canopy cover above $8 \mathrm{~m}$ were negatively associated with the first axis (higher values in ancient forest and lower values in recent forest), while $\mathrm{pH} \mathrm{H}_{2} \mathrm{O}$ and $\mathrm{P}$ content displayed the opposite trend (lower values in ancient forest and higher values in recent forest; Fig. 3a and Table 3). Canopy cover 2-8 m was positively associated with the second ordination axis, indicating higher subcanopy cover in deciduous stands (Fig. 3a and Table 3).

Since the first two RLQ axes were respectively closely related to forest continuity and tree species, the correlations between these gradients and plant traits were easy to infer. All the traits were correlated with at least one RLQ axis (Fig. 3b and Table 4). However, the traits or trait categories that correlated with the first axis (forest continuity) differed from the traits that correlated with the second axis (tree species): only seed length and zoochory were significantly correlated with the first two axes (Table 4). 
Author-produced version of the article published in Applied Vegetation Science, 2017, 20, 468-481.

The original publication is available at http://onlinelibrary.wiley.com

DOI: 10.1111/avsc.12296

Forest core species, leaf dry matter content and bryophytes were highly, negatively correlated with the first axis $(P<0.001)$, indicating increasing values from recent to ancient forest (Table 4$)$. C-coordinate, S-coordinate and seed length were also negatively correlated but to a lower extent $(P<0.01$ or 0.05$)$. Conversely, R-coordinate, indicator value for soil $\mathrm{pH}$ and soil nitrogen $(\mathrm{N})$, specific leaf area and annuals/biennials were highly positively correlated with the first axis, indicating decreasing values from recent to ancient forest. Perennial herbs, species reproducing by seed and vegetatively (sv.vvs), barochory and zoochory were also positively correlated with the first axis $(P<0.01$ or $P<0.05)$. Bivariate associations between categories of forest continuity and species traits indicated that peripheral species and shrubs/trees were associated with recent forests, while larger seeds and earlier end-of-flowering characterised intermediate forests (Table 5).

Seed weight and length, myrmecochory and zoochory were positively associated with the second axis $(P<0.01)$ with higher values in deciduous forests (Table 4). Conversely, indicator value for light, start and end of flowering, anemochory and seed bank longevity index were negatively associated with the second axis $(P<0.01)$, meaning that these traits had higher values in coniferous stands. In addition, proportion of forest core species was higher in deciduous forests (Table 5), proportion of annuals and biennials was particularly high in recent pine plantations (Fig. 3b), and several species were located in this bottom right corner of the first RLQ factorial map (Appendix S7). We noted that the associations between the second axis of RLQ and traits (Table 4) and bivariate associations between tree species and traits (Table 5) were not consistent: only forest core species and indicator value for $L$ were significantly related to tree species in Table 5, meaning that the associations between the second RLQ axis and traits should be interpreted with caution.

The ad-hoc two-way ANOVA applied to forest core species richness revealed that the effects of forest continuity and tree species were significant $(P<0.001$ and $P<0.01$ respectively) but not the interaction: species richness increased from recent to ancient forest and was higher under oak (Fig. 4).

\section{Discussion}

Our results showed that forest continuity and tree species acted as ecological filters on the taxonomic and functional composition of forest understory plant communities. Plant trait composition varied along the forest continuity and tree species gradients according to ecological performance, resource requirement, persistence, regeneration and dispersal ability. As past land use was correlated to the first RLQ axis (87\% of total inertia) while tree species was correlated to the second one (8\%), our results indicated that the magnitude of past land use effect on plant functional composition was globally stronger than the effect of tree species, in line with Kelemen et al. (2014).

\section{Role of past land use}

Previous cultivation has long-lasting effects on the upper forest soil horizon, e.g. nitrogen and carbon depletion, phosphorus enrichment, and soil pH rise (Hermy \& Verheyen 2007; Berthrong et al. 2009; 
Author-produced version of the article published in Applied Vegetation Science, 2017, 20, 468-481.

The original publication is available at http://onlinelibrary.wiley.com

DOI: 10.1111/avsc.12296

Brudvig et al. 2013). Overall, land use legacies on topsoil chemical properties are related to three processes: (i) soil acidification and base cation loss caused by nutrients being redistributed from soils to biomass in aggrading forest ecosystems (Jobbagy \& Jackson 2003), (ii) lower rates of nitrification and higher nitrate leaching in the soil, which may result from increased soil acidity (Hermy \& Verheyen 2007), and (iii) past amendment and fertiliser application (lime and manure) in former agricultural soils that have enriched soil P and base cation levels (Compton \& Boone 2000). As expected, we found a pronounced agricultural legacy on understory plant communities and progressive recovery to ancient forest communities, as evidenced by the first axis of the CCA (Fig. 2). As resource gradients (nutrient and light) did not explain all the variability in plant community composition (see pCCA), this strongly suggests that factors other than local habitat quality constrained the establishment of forest understory plants in post-agricultural forests, e.g. time since disturbance, distance to propagule source and species dispersal capacity. After deforestation and subsequent cultivation, species typical of ancient forests are soon lost from the soil seed bank (Hermy \& Verheyen 2007). After the abandonment of agriculture, the land is colonised by open habitat herbaceous plants, but ruderal species rapidly disappear and are replaced by competitive species (pioneer trees and shrubs) (Hermy \& Verheyen 2007). In our study, plant C-S-R signature was characterised by a strong decrease in R-component and an increase in $\mathrm{C}$ and $\mathrm{S}$-components from recent to ancient forest. The variation in R-component can be linked to ploughing and other forms of soil disturbance and the increase in C-axis to land abandonment and increased competitive exclusion (Hunt et al. 2004). Long after the reconstitution of a dominant tree layer, the plant communities still differ from ancient forests: many plants typical of ancient forests are lacking due to their limited dispersal capacity (Hermy \& Verheyen 2007). In accordance with previous studies (Verheyen et al. 2003; Bergès et al. 2016), we showed that proportion of zoochory was slightly higher and seed length lower in recent forests (Table 4).

Plant communities in recent forests were characterised by a larger proportion of nutrient-demanding, ruderal and short-lived species, but also tree and shrub species. Some of the shrubs in our recent forests could be considered as relicts from previous stages in vegetation succession (Verheyen \& Hermy 2001). The lower specific leaf area and higher leaf dry matter content detected in ancient forests confirms that species in environments with resource stress displayed these functional features compared with resource-rich environments (higher soil $\mathrm{pH}$ and $\mathrm{N}$ and $\mathrm{P}$ availability), such as recent forests (Cornelissen et al. 2003). Analogous responses of specific leaf area and leaf dry matter content to land use change were noted in grasslands, where abandonment of land tended to favour species with reduced acquisition capacities and increased nutrient conservation efficiency (Garnier et al. 2007).

\section{Role of tree species composition}

Many conifer species, but not all (Barbier et al. 2008), tend to acidify soils more than deciduous trees through several processes (Verstraeten et al. 2013; Augusto et al. 2015). Although we detected significant differences in $\mathrm{pH}, \mathrm{C} / \mathrm{N}$ and phosphorus content between deciduous and coniferous stands 
Author-produced version of the article published in Applied Vegetation Science, 2017, 20, 468-481.

The original publication is available at http://onlinelibrary.wiley.com

DOI: 10.1111/avsc.12296

(Table S1 and Fig. S1), the fourth-corner analysis did not detect any significant associations between plant resource requirements (indicator values for $\mathrm{pH}$ and $\mathrm{N}$ ) and tree species composition (Tables 4 and 5). This may be because RLQ is simply an ordination of the fourth-corner statistics and so does not build a truly multi-trait multi-environment model in the sense of regression analysis, i.e. is unable to reveal additive effects (Jamil et al. 2013). In our case, variations in soil properties were much stronger along the forest continuity gradient than between deciduous and coniferous forests: indeed, tree species effect was significant only after correcting for forest continuity effect (data not shown). Plant functional composition differed between oak and pine mainly for shade tolerance (Table 5), in line with a less dense canopy cover between 2 and $8 \mathrm{~m}$ under pine (Fig. S1) and the highest indicator value for light detected for the understory vegetation under P. sylvestris among six tree species (Augusto et al. 2003). The higher proportion of anemochory and lighter and shorter seeds in pine plantations (Table 4) could also be explained by their more open subcanopy, which could facilitate seed dispersal by wind. A higher proportion of vernal plants, which must bloom before canopy leaf expansion, could explain the earlier period of flowering observed in oak (Table 4).

\section{Role of regeneration mode and forest management}

Regardless of tree species, site preparation before plantation implies more intense forest floor and topsoil disturbances (e.g. ploughing and soil scarification) compared with naturally regenerated deciduous stands (Balandier et al. 2006). This could explain why recent pine plantations exhibited higher proportions of ruderal and wind-dispersed species (Boch et al. 2013). Weed control by mechanical or herbicide release treatments can also deeply modify plant communities and promote the establishment of species adapted to disturbance (Balandier et al. 2006). Pine plantations in postagricultural forests had a low proportion of ant-dispersed species, which can be explained by their reduced colonisation capacity after removal from a site (Aubin et al. 2008), and hosted plants with a higher seed bank longevity (Table 4), which is a strategy to survive in case of frequent site disturbances. Conserving a substantial part of the pre-existing plant communities in plantation forests thus has a positive impact on plant diversity and vegetation recovery (Hartley 2002).

Likewise, the silviculture applied to the stand plays a role because it modifies light transmittance to the ground and causes regular soil disturbance due to logging machines (Verstraeten et al. 2013). Moreover, shrub and subcanopy strata can be controlled during thinnings at the thicket, sapling and pole stages of the stand and could mitigate soil acidification in pine plantations (Van Nevel et al. 2014). Silviculture in conifer plantations prevents natural development of a dense tree subcanopy, as shown by the much lower canopy cover between 2 and 8 m under pine (Fig. 3a and Fig. S1). On the other hand, intense litter and topsoil disturbances could also occur in oak to favour natural deciduous regeneration in actively managed stands. Consequently, our results cannot be interpreted as pure tree effects, but rather a combination of tree species effect and their associated management (Thomaes et al. 2012). 
Author-produced version of the article published in Applied Vegetation Science, 2017, 20, 468-481.

The original publication is available at http://onlinelibrary.wiley.com

DOI: 10.1111/avsc.12296

\section{Understory succession differed between pine plantations and naturally regenerated oak stands}

Soil chemical parameters in recent forests under oak and pine were very close and confirmed that preafforestation site conditions were comparable (Fig. S1). Litter accumulation was higher and litter degradation lower under pine, and these differences increased with time after pine plantation (Fig. S1). In contradiction with our initial hypothesis and with the patterns observed on soil, CCA indicated higher composition similarity between deciduous and coniferous ancient forests than between corresponding recent forests (Fig. 2), i.e. a convergence between pine and oak plant succession with increasing forest continuity. To explain the higher dissimilarity in recent forests, we noted that recent pine plantations displayed a higher proportion of short-lived species (Fig. 3b). Floristic difference between pine plantations and deciduous stands in recent forests (Fig. 2) may be related to a higher maintenance of ruderal and nutrient-demanding species due to more intense initial site disturbances combined with lower canopy cover under pine (Thomaes et al. 2014). Then, the effect of the disturbance tends to dissipate progressively after the stand-initiating disturbance (Fourrier et al. 2015), and other ecological filters take over: soil acidification and phosphorus diminution reduced the pool of ruderal and nutrientdemanding species and subcanopy development reduced light-loving competitors and promoted the establishment of shade-tolerant forest herbs (De Keersmaeker et al. 2011). Increasing soil acidification and litter accumulation in intermediate and ancient pine plantations limited the colonisation of acidintolerant forest species, while promoting acid-tolerant forest species (Thomaes et al. 2013), which partly explains why plant dissimilarity between pines and oaks persisted in intermediate and ancient forests (Fig. 2).

In accordance with our initial hypothesis, oak forests hosted a slightly higher proportion of forest core species (Table 5) and a significantly higher number of forest core species (Fig. 4), which suggests that migration or recruitment of forest specialists were delayed in pine plantations on farmlands. This contrasts with the comparably efficient migration of herbaceous forest specialists into recent coniferous and deciduous stands observed by Wulf and Heinken (2008). Our result is consistent with previous experiments that underlined that acidifying tree species could severely limit germination and survival of ancient forest species (Thomaes et al. 2014).

Overall, understory succession in post-agricultural stands varied between pine plantations and naturallyregenerated oak stands, and differences persisted in ancient forests. In line with Fourrier et al. (2015), we attributed these differences to the intensity of the initial disturbance, and then to tree species and contrasting stand management.

\section{Conclusion}

Plant communities and traits in pine plantations under recent and ancient forests differed from similar sites with pedunculate and sessile oaks. Past land use and tree species substitution had combined effects on topsoil chemical properties, plant community and plant traits, and the impacts of past land use were globally stronger than those of conifer plantation. This hierarchy has to be validated in other ecological 
Author-produced version of the article published in Applied Vegetation Science, 2017, 20, 468-481.

The original publication is available at http://onlinelibrary.wiley.com

DOI: 10.1111/avsc.12296

contexts and tree species. Understory plant succession differed between pine plantations and naturallyregenerated oak stands, under the influence of several ecological drivers: soil disturbance and understory vegetation removal at the beginning, and then tree species and stand management during stand development, where soil acidification, litter accumulation, canopy cover and dispersal and recruitment limitations play a major role. Our study underlines the slow process of recovery of recent forests towards ancient forest plant communities. In our study area, conifer plantation resulted in a long-lasting distinct taxonomic and functional trait composition. In ancient deciduous forests, we therefore advise applying natural regeneration and favouring native deciduous tree species to maintain or restore ancient forest plant communities.

\section{Acknowledgements}

The authors dedicate this article to the memory of their colleague Emmanuelle Dauffy-Richard, who passed away prematurely and who is sorely missed. The authors thank Adélie Chevalier for her precious help during floristic and dendrometric sampling, the National Forest Office and the CNPF Ile-de-France - Centre for their help during site selection. They are also very grateful to three reviewers and the coordinating Editor who contribute to improve earlier versions of the manuscript. This work was funded by the FORGECO project (ANR-09-STRA-02-02). The UMR 1137 Forest Ecology and Ecophysiology is supported by a grant overseen by the French National Research Agency (ANR) as part of the "Investissements d'Avenir" program (ANR-11-LABX-0002-01, Lab of Excellence ARBRE).

\section{References}

Aubin, I., Messier, C. \& Bouchard, A. 2008. Can plantations develop understory biological and physical attributes of naturally regenerated forests? Biological Conservation 141: 2461-2476.

Augusto, L., De Schrijver, A., Vesterdal, L., Smolander, A., Prescott, C. \& Ranger, J. 2015. Influences of evergreen gymnosperm and deciduous angiosperm tree species on the functioning of temperate and boreal forests. Biological Reviews 90: 444-466.

Augusto, L., Dupouey, J.L. \& Ranger, J. 2003. Effects of tree species on understory vegetation and environmental conditions in temperate forests. Annals of Forest Science 60: 823-831.

Baeten, L., Bauwens, B., De Schrijver, A., De Keersmaeker, L., Van Calster, H., Vandekerkhove, K., Roelandt, B., Beeckman, H. \& Verheyen, K. 2009a. Herb layer changes (1954-2000) related to the conversion of coppice-with-standards forest and soil acidification. Applied Vegetation Science 12: 187-197.

Baeten, L., Hermy, M. \& Verheyen, K. 2009b. Environmental limitation contributes to the differential colonization capacity of two forest herbs. Journal of Vegetation Science 20: 209-223.

Balandier, P., Collet, C., Miller, J.H., Reynolds, P.E. \& Zedaker, S.M. 2006. Designing forest vegetation management strategies based on the mechanisms and dynamics of crop tree competition by neighbouring vegetation. Forestry 79: 3-27. 
Author-produced version of the article published in Applied Vegetation Science, 2017, 20, 468-481.

The original publication is available at http://onlinelibrary.wiley.com

DOI: 10.1111/avsc.12296

Barbier, S., Balandier, P. \& Gosselin, F. 2009. Influence of several tree traits on rainfall partitioning in temperate and boreal forests: a review. Annals of Forest Science 66.

Barbier, S., Gosselin, F. \& Balandier, P. 2008. Influence of tree species on understory vegetation diversity and mechanisms involved - A critical review for temperate and boreal forests. Forest Ecology and Management 254: 1-15.

Bergès, L., Avon, C., Arnaudet, L., Archaux, F., Chauchard, S. \& Dupouey, J.L. 2016. Past landscape explains forest periphery-to-core gradient of understory plant communities in a reforestation context. Diversity and Distributions 22: 3-16.

Berthrong, S.T., Jobbagy, E.G. \& Jackson, R.B. 2009. A global meta-analysis of soil exchangeable cations, pH, carbon, and nitrogen with afforestation. Ecological Applications 19: 2228-2241.

Boch, S., Prati, D., Muller, J., Socher, S., Baumbach, H., Buscot, F., Gockel, S., Hemp, A., Hessenmoller, D., Kalko, E.K.V., Linsenmair, K.E., Pfeiffer, S., Pommer, U., Schoning, I., Schulze, E.D., Seilwinder, C., Weisser, W.W., Wells, K. \& Fischer, M. 2013. High plant species richness indicates management-related disturbances rather than the conservation status of forests. Basic and Applied Ecology 14: 496-505.

Boothroyd-Roberts, K., Gagnon, D. \& Truax, B. 2013. Can hybrid poplar plantations accelerate the restoration of forest understory attributes on abandoned fields? Forest Ecology and Management 287: 77-89.

Borcard, D., Legendre, P. \& Drapeau, P. 1992. Partialling out the spatial component of ecological variation. Ecology 73: 1045-1055.

Bremer, L.L. \& Farley, K.A. 2010. Does plantation forestry restore biodiversity or create green deserts? A synthesis of the effects of land-use transitions on plant species richness. Biodiversity and Conservation 19: 3893-3915.

Brudvig, L.A., Grman, E., Habeck, C.W., Orrock, J.L. \& Ledvina, J.A. 2013. Strong legacy of agricultural land use on soils and understory plant communities in longleaf pine woodlands. Forest Ecology and Management 310: 944-955.

Compton, J.E. \& Boone, R.D. 2000. Long-term impacts of agriculture on soil carbon and nitrogen in New England forests. Ecology 81: 2314-2330.

Cornelissen, J.H.C., Lavorel, S., Garnier, E., Diaz, S., Buchmann, N., Gurvich, D.E., Reich, P.B., ter Steege, H., Morgan, H.D., van der Heijden, M.G.A., Pausas, J.G. \& Poorter, H. 2003. A handbook of protocols for standardised and easy measurement of plant functional traits worldwide. Australian Journal of Botany 51: 335-380.

Cramer, V.A., Hobbs, R.J. \& Standish, R.J. 2008. What's new about old fields? Land abandonment and ecosystem assembly. Trends in Ecology \& Evolution 23: 104-112.

De Keersmaeker, L., Vandekerkhove, K., Verstraeten, A., Baeten, L., Verschelde, P., Thomaes, A., Hermy, M. \& Verheyen, K. 2011. Clear-felling effects on colonization rates of shade-tolerant forest herbs into a post-agricultural forest adjacent to ancient forest. Applied Vegetation Science 14: 75-83. 
Author-produced version of the article published in Applied Vegetation Science, 2017, 20, 468-481.

The original publication is available at http://onlinelibrary.wiley.com

DOI: 10.1111/avsc.12296

De Schrijver, A., Vesterdal, L., Hansen, K., De Frenne, P., Augusto, L., Achat, D.L., Staelens, J., Baeten, L., De Keersmaeker, L., De Neve, S. \& Verheyen, K. 2012. Four decades of postagricultural forest development have caused major redistributions of soil phosphorus fractions. Oecologia 169: 221-234.

Dray, S., Choler, P., Doledec, S., Peres-Neto, P.R., Thuiller, W., Pavoine, S. \& ter Braak, C.J.F. 2014. Combining the fourth-corner and the RLQ methods for assessing trait responses to environmental variation. Ecology 95: 14-21.

Ellenberg, H., Weber, H.E., Düll, R., Wirth, V., Werner, W. \& Pauliflen, D. 1992. Zeigerwerte von Pflanzen in Mitteleuropa. Scripta geobotanica 18: 1-258.

Favre, C., Grel, A., Granier, E., Cosserat-Mangeot, R., Bachacou, J. \& Dupouey, J.L. 2013. Digitalisation des cartes anciennes. Manuel pour la vectorisation de l'usage des sols et le géoréférencement des minutes 1:40000 de la carte d'Etat-Major (v. 12.7.3). In, pp. 54. INRA.

Fourrier, A., Bouchard, M. \& Pothier, D. 2015. Effects of canopy composition and disturbance type on understorey plant assembly in boreal forests. Journal of Vegetation Science 26: 1225-1237.

Garnier, E., Lavorel, S., Ansquer, P., Castro, H., Cruz, P., Dolezal, J., Eriksson, O., Fortunel, C., Freitas, H., Golodets, C., Grigulis, K., Jouany, C., Kazakou, E., Kigel, J., Kleyer, M., Lehsten, V., Leps, J., Meier, T., Pakeman, R., Papadimitriou, M., Papanastasis, V.P., Quested, H., Quetier, F., Robson, M., Roumet, C., Rusch, G., Skarpe, C., Sternberg, M., Theau, J.P., Thebault, A., Vile, D. \& Zarovali, M.P. 2007. Assessing the effects of land-use change on plant traits, communities and ecosystem functioning in grasslands: A standardized methodology and lessons from an application to 11 European sites. Annals of Botany 99: 967-985.

Gégout, J.C., Coudun, C., Bailly, G. \& Jabiol, B. 2005. EcoPlant: A forest site database linking floristic data with soil and climate variables. Journal of Vegetation Science 16: 257-260.

Hagen-Thorn, A., Callesen, I., Armolaitis, K. \& Nihlgard, B. 2004. The impact of six European tree species on the chemistry of mineral topsoil in forest plantations on former agricultural land. Forest Ecology and Management 195: 373-384.

Härdtle, W., von Oheimb, G. \& Westphal, C. 2003. The effects of light and soil conditions on the species richness of the ground vegetation of deciduous forests in northern Germany (SchleswigHolstein). Forest Ecology and Management 182: 327-338.

Hartley, M.J. 2002. Rationale and methods for conserving biodiversity in plantation forests. Forest Ecology and Management 155: 81-95.

Hermy, M. \& Verheyen, K. 2007. Legacies of the past in the present-day forest biodiversity: a review of past land-use effects on forest plant species composition and diversity. Ecological Research 22: 361-371.

Hintze, C., Heydel, F., Hoppe, C., Cunze, S., Konig, A. \& Tackenberg, O. 2013. D-3: The Dispersal and Diaspore Database - Baseline data and statistics on seed dispersal. Perspectives in Plant Ecology Evolution and Systematics 15: 180-192. 
Author-produced version of the article published in Applied Vegetation Science, 2017, 20, 468-481.

The original publication is available at http://onlinelibrary.wiley.com

DOI: 10.1111/avsc.12296

Hunt, R., Hodgson, J.G., Thompson, K., Bungener, P., Dunnett, N.P. \& Askew, A.P. 2004. A new practical tool for deriving a functional signature for herbaceous vegetation. Applied Vegetation Science 7: 163-170.

Jamil, T., Ozinga, W.A., Kleyer, M. \& Ter Braak, C.J.F. 2013. Selecting traits that explain speciesenvironment relationships: A generalized linear mixed model approach. Journal of Vegetation Science 24: 988-1000.

Jobbagy, E.G. \& Jackson, R.B. 2003. Patterns and mechanisms of soil acidification in the conversion of grasslands to forests. Biogeochemistry 64: 205-229.

Kelemen, K., Kriván, A. \& Standovár, T. 2014. Effects of land-use history and current management on ancient woodland herbs in Western Hungary. Journal of Vegetation Science 25: 172-183.

Kleyer, M., Bekker, R.M., Knevel, I.C., Bakker, J.P., Thompson, K., Sonnenschein, M., Poschlod, P., van Groenendael, J.M., Klimes, L., Klimesova, J., Klotz, S., Rusch, G.M., Hermy, M., Adriaens, D., Boedeltje, G., Bossuyt, B., Dannemann, A., Endels, P., Gotzenberger, L., Hodgson, J.G., Jackel, A.K., Kuhn, I., Kunzmann, D., Ozinga, W.A., Romermann, C., Stadler, M., Schlegelmilch, J., Steendam, H.J., Tackenberg, O., Wilmann, B., Cornelissen, J.H.C., Eriksson, O., Garnier, E. \& Peco, B. 2008. The LEDA Traitbase: a database of life-history traits of the Northwest European flora. Journal of Ecology 96: 1266-1274.

Kleyer, M., Dray, S., de Bello, F., Leps, J., Pakeman, R.J., Strauss, B., Thuiller, W. \& Lavorel, S. 2012. Assessing species and community functional responses to environmental gradients: which multivariate methods? Journal of Vegetation Science 23: 805-821.

Kooijman, A. 2010. Litter quality effects of beech and hornbeam on undergrowth species diversity in Luxembourg forests on limestone and decalcified marl. Journal of Vegetation Science 21: 248-261.

Kühn, I., Durka, W. \& Klotz, S. 2004. BiolFlor - a new plant-trait database as a tool for plant invasion ecology. Diversity and Distributions 10: 363-365.

Legendre, P., Galzin, R. \& HarmelinVivien, M.L. 1997. Relating behavior to habitat: Solutions to the fourth-corner problem. Ecology 78: 547-562.

Leuschner, C., Wulf, M., Bäuchler, P. \& Hertel, D. 2013. Soil C and nutrient stores under Scots pine afforestations compared to ancient beech forests in the German Pleistocene: The role of tree species and forest history. Forest Ecology and Management 310: 405-415.

Mather, A.S., Fairbairn, J. \& Needle, C.L. 1999. The course and drivers of the forest transition: The case of France. Journal of Rural Studies 15: 65-90.

Pellissier, V., Bergès, L., Nedeltcheva, T., Schmitt, M.C., Avon, C., Cluzeau, C. \& Dupouey, J.L. 2013. Understorey plant species show long-range spatial patterns in forest patches according to distanceto-edge. Journal of Vegetation Science 24: 9-24.

Ponge, J.F., Chevalier, R. \& Loussot, P. 2002. Humus index: An integrated tool for the assessment of forest floor and topsoil properties. Soil Science Society of America Journal 66: 1996-2001. 
Author-produced version of the article published in Applied Vegetation Science, 2017, 20, 468-481.

The original publication is available at http://onlinelibrary.wiley.com

DOI: 10.1111/avsc.12296

Reich, P.B., Oleksyn, J., Modrzynski, J., Mrozinski, P., Hobbie, S.E., Eissenstat, D.M., Chorover, J., Chadwick, O.A., Hale, C.M. \& Tjoelker, M.G. 2005. Linking litter calcium, earthworms and soil properties: a common garden test with 14 tree species. Ecology Letters 8: 811-818.

Sciama, D., Augusto, L., Dupouey, J.L., Gonzalez, M. \& Dominguez, C.M. 2009. Floristic and ecological differences between recent and ancient forests growing on non-acidic soils. Forest Ecology and Management 258: 600-608.

Thomaes, A., De Keersmaeker, L., De Schrijver, A., Baeten, L., Vandekerkhove, K., Verstraeten, G. \& Verheyen, K. 2013. Can soil acidity and light help to explain tree species effects on forest herb layer performance in post-agricultural forests? Plant and Soil 373: 183-199.

Thomaes, A., De Keersmaeker, L., Van Calster, H., De Schrijver, A., Vandekerkhove, K., Verstraeten, G. \& Verheyen, K. 2012. Diverging effects of two contrasting tree species on soil and herb layer development in a chronosequence of post-agricultural forest. Forest Ecology and Management 278: 90-100.

Thomaes, A., De Keersmaeker, L., Verschelde, P., Vandekerkhove, K. \& Verheyen, K. 2014. Tree species determine the colonisation success of forest herbs in post-agricultural forests: Results from a 9 yr introduction experiment. Biological Conservation 169: 238-247.

Tullus, T., Tullus, A., Roosaluste, E., Kaasik, A., Lutter, R. \& Tullus, H. 2013. Understorey vegetation in young naturally regenerated and planted birch (Betula spp.) stands on abandoned agricultural land. New Forests 44: 591-611.

Van Nevel, L., Mertens, J., De Schrijver, A., De Neve, S. \& Verheyen, K. 2014. Can shrub species with higher litter quality mitigate soil acidification in pine and oak forests on poor sandy soils? Forest Ecology and Management 330: 38-45.

Verheyen, K. \& Hermy, M. 2001. An integrated analysis of the spatio-temporal colonization patterns of forest plant species. Journal of Vegetation Science 12: 567-578.

Verheyen, K., Honnay, O., Motzkin, G., Hermy, M. \& Foster, D.R. 2003. Response of forest plant species to land-use change: a life-history trait-based approach. Journal of Ecology 91: 563-577.

Verstraeten, G., Baeten, L., De Frenne, P., Vanhellemont, M., Thomaes, A., Boonen, W., Muys, B. \& Verheyen, K. 2013. Understorey vegetation shifts following the conversion of temperate deciduous forest to spruce plantation. Forest Ecology and Management 289: 363-370.

Violle, C., Navas, M.L., Vile, D., Kazakou, E., Fortunel, C., Hummel, I. \& Garnier, E. 2007. Let the concept of trait be functional! Oikos 116: 882-892.

WRB, I.W.G. 2015. World Reference Base for Soil Resources 2014, update 2015 - International soil classification system for naming soils and creating legends for soil maps. In, pp. 191, Rome.

Wulf, M. \& Heinken, T. 2008. Colonization of recent coniferous versus deciduous forest stands by vascular plants at the local scale. Applied Vegetation Science 11: 307-316.

Wulf, M. \& Naaf, T. 2009. Herb layer response to broadleaf tree species with different leaf litter quality and canopy structure in temperate forests. Journal of Vegetation Science 20: 517-526. 
Author-produced version of the article published in Applied Vegetation Science, 2017, 20, 468-481.

The original publication is available at http://onlinelibrary.wiley.com

DOI: 10.1111/avsc.12296 


\section{Supporting Information}

590 Additional supporting information may be found in the online version of this article.

592 Appendix S1. Detailed analysis of humus form, soil and stand variations among sites

593 Appendix S2. Plant trait data

594 Appendix S3. Set of hypotheses on the expected relationship between plant traits and ecological 595 gradients

596 Appendix S4. Detailed methodology to analyse the relationship between plant traits and forest 597 continuity and tree species

598 Appendix S5. Individual species response to forest continuity and tree species

599 Appendix S6. Detailed results of multiple logistic regression models applied to individual species

600 Appendix S7. Ordination of plant species in the first RLQ factorial map

601 
Author-produced version of the article published in Applied Vegetation Science, 2017, 20, 468-481.

The original publication is available at http://onlinelibrary.wiley.com

DOI: 10.1111/avsc.12296

602

603

Table 1. Definition of the six sampling units based on forest continuity (according to past land use maps of 1840 and aerial photographs taken in 1949) and tree species, and number of sampling points.

Tree species composition
deciduous
coniferous
Total
(Q. petraea/Q. robur)
(Pinus sylvestris)

\begin{tabular}{lcc}
\hline ancient forest & AF-DEC: deciduous & AF-CON: plantation of \\
(AF) & ancient forest & pines between 1840 et \\
& 1949 on deciduous \\
& ancient forest
\end{tabular}

15

12

27

\begin{tabular}{lccc}
\hline $\begin{array}{l}\text { intermediate- } \\
\text { age forest } \\
\text { (IF) }\end{array}$ & $\begin{array}{c}\text { IF-DEC: natural } \\
\text { colonisation of deciduous } \\
\text { tree species between } 1840 \\
\text { and 1949 on former } \\
\text { agricultural land }\end{array}$ & $\begin{array}{c}\text { IF-CON: plantation of } \\
\text { pines between 1840 and } \\
\text { 1949 on former } \\
\text { agricultural land }\end{array}$ & \\
& $\begin{array}{c}16 \\
\text { RF-DEC: natural }\end{array}$ & RF-CON: plantation of & 29 \\
(RF) & $\begin{array}{c}\text { colonisation of deciduous } \\
\text { tree species after 1949 on } \\
\text { former agricultural land }\end{array}$ & former agricultural land & \\
& 8 & 1949 on & 24 \\
\hline Total & 39 & 41 & 80
\end{tabular}

604

605 
Author-produced version of the article published in Applied Vegetation Science, 2017, 20, 468-481.

The original publication is available at http://onlinelibrary.wiley.com

DOI: 10.1111/avsc.12296

Table 2. The 15 plant traits analysed by ecological function: trait name, data sources, type, trait category

607 (continuous: C; ordinal: O; nominal: N) and code. Data sources: Catminat

608 (http://philippe.julve.pagesperso-orange.fr/catminat.htm), Ecoplant (Gégout et al. 2005), Ellenberg

609 indicator values (Ellenberg et al. 1992), LEDA (Kleyer et al. 2008), Biolflor (Kühn et al. 2004) and D 3

610 (Hintze et al. 2013).

\begin{tabular}{|c|c|c|c|c|c|}
\hline $\begin{array}{l}\text { Ecological } \\
\text { function }\end{array}$ & Plant trait & Data source & Type & Category & Code \\
\hline \multirow[t]{2}{*}{$\begin{array}{l}\text { Ecological } \\
\text { performance }\end{array}$} & $\begin{array}{l}\text { Habitat preference: } \\
\text { distance to edge }\end{array}$ & $\begin{array}{l}\text { Pellissier et al. } \\
\text { (2013) }\end{array}$ & $\mathrm{N}$ & $\begin{array}{l}\text { Forest core species } \\
\text { Forest peripheral species }\end{array}$ & $\begin{array}{l}\text { HAB.core } \\
\text { HAB.peripheral }\end{array}$ \\
\hline & CSR strategy & $\begin{array}{l}\text { Hunt et al. } \\
\text { (2004) }\end{array}$ & $\mathrm{C}$ & $\begin{array}{l}\text { C-coordinate } \\
\text { S-coordinate } \\
\text { R-coordinate }\end{array}$ & $\begin{array}{l}\text { C.coord } \\
\text { S.coord } \\
\text { R.coord }\end{array}$ \\
\hline \multirow{3}{*}{$\begin{array}{l}\text { Resource } \\
\text { requirement }\end{array}$} & Ind. value for $\mathrm{pH}$ & Ecoplant & $\mathrm{O}$ & - & $\mathrm{pH}$ \\
\hline & Ind. value for $\mathrm{N}$ & Ellenberg & $\mathrm{O}$ & - & $\mathrm{N}$ \\
\hline & Ind. value for $\mathrm{L}$ & Ellenberg & $\mathrm{O}$ & - & $\mathrm{L}$ \\
\hline \multirow[t]{2}{*}{ Persistence } & Specific leaf area & LEDA & $\mathrm{C}$ & - & SLA \\
\hline & Leaf dry matter content & LEDA & $\mathrm{C}$ & - & LDMC \\
\hline \multirow[t]{9}{*}{ Regeneration } & \multirow{4}{*}{$\begin{array}{l}\text { Plant life span }+ \\
\text { bryophytes }\end{array}$} & \multirow[t]{4}{*}{ Catminat } & \multirow[t]{4}{*}{$\mathrm{N}$} & annual or biennial & PLS.ann.bie \\
\hline & & & & perennial herb & PLS.per.herb \\
\hline & & & & shrub pr tree & PLS.shr.tree \\
\hline & & & & bryophyte & PLS.bryo \\
\hline & \multirow[t]{3}{*}{ Reproduction type } & \multirow[t]{3}{*}{ Biolflor } & \multirow[t]{3}{*}{$\mathrm{N}$} & s: by seed only & REPRO.s \\
\hline & & & & $\begin{array}{l}\text { ssv: mostly by seed, rarely } \\
\text { vegetative }\end{array}$ & REPRO.ssv \\
\hline & & & & $\begin{array}{l}\text { sv: by seed and vegetatively; vvs: } \\
\text { mostly vegetative, rarely by seed }\end{array}$ & REPRO.sv.vvs \\
\hline & Start of flowering & Catminat & $\mathrm{C}$ & - & beg.fl \\
\hline & End of flowering & Catminat & $\mathrm{C}$ & - & end.fl \\
\hline \multirow[t]{7}{*}{ Dispersion } & \multirow[t]{4}{*}{ Dispersal mode } & \multirow[t]{4}{*}{ Catminat } & \multirow[t]{4}{*}{$\mathrm{N}$} & anemochory & DISP.anemo \\
\hline & & & & barochory & DISP.baro \\
\hline & & & & myrmecochory & DISP.myrmeco \\
\hline & & & & zoochory & DISP.zoo \\
\hline & Seed weight (mg) & $\mathrm{D}^{3}$ and Biolflor & $\mathrm{C}$ & $\log$ transformed & $\log . \mathrm{SW}$ \\
\hline & Seed length (mm) & $\mathrm{D}^{3}$ and Biolflor & $\mathrm{C}$ & log transformed & $\log . S L$ \\
\hline & $\begin{array}{l}\text { Seed bank longevity } \\
\text { index }\end{array}$ & LEDA & $\mathrm{C}$ & $\begin{array}{l}0: \text { transient; } 0.5 \text { : short-term } \\
\text { persistent; } 1: \text { long-term persistent }\end{array}$ & SBLI \\
\hline
\end{tabular}

611 
Author-produced version of the article published in Applied Vegetation Science, 2017, 20, 468-481.

The original publication is available at http://onlinelibrary.wiley.com

DOI: 10.1111/avsc.12296

612 Table 3. Trait responses to forest continuity, tree species and other environmental variables using RLQ:

613 fourth-corner tests (Pearson correlation coefficient $r$ ) between the first two RLQ axes for plant traits

614 (AxisQ1 and AxisQ2) and forest continuity, tree species and environmental variables. $P$ values were

615 adjusted for multiple comparisons using the FDR (false discovery rate) procedure. See also Fig. 3 for

616 codes for environmental variables.

\begin{tabular}{llcccc}
\hline \hline & & \multicolumn{2}{c}{ AxisQ1 } & \multicolumn{2}{c}{ AxisQ2 } \\
Code & Variable description & $r$ & $P$ value & $r$ & $P$ value \\
\hline $\mathrm{AF}$ & Ancient forest & -0.309 & $* * *$ & -0.068 & $\mathrm{NS}$ \\
$\mathrm{IF}$ & Intermediate-age forest & -0.141 & $* * *$ & 0.082 & $*$ \\
$\mathrm{RF}$ & Recent forest & 0.433 & $* * *$ & -0.016 & $\mathrm{NS}$ \\
$\mathrm{CON}$ & Coniferous forest & 0.025 & $\mathrm{NS}$ & -0.152 & $* * *$ \\
$\mathrm{DEC}$ & Deciduous forest & -0.025 & $\mathrm{NS}$ & 0.152 & $* * *$ \\
$\mathrm{Humus}$ index & - & -0.430 & $* * *$ & -0.063 & $\mathrm{NS}$ \\
$\mathrm{pH} \mathrm{H}_{2} \mathrm{O}$ & - & 0.434 & $* * *$ & 0.006 & $\mathrm{NS}$ \\
$\log \left(\mathrm{P}_{2} \mathrm{O}_{5}+1\right)$ & - & 0.465 & $* * *$ & -0.048 & $\mathrm{NS}$ \\
$\mathrm{CC} 2-8 \mathrm{~m}$ & Canopy cover $2-8 \mathrm{~m}$ & 0.084 & $\mathrm{NS}$ & 0.148 & $* * *$ \\
$\mathrm{CC}>8 \mathrm{~m}$ & Canopy cover $>8 \mathrm{~m}$ & -0.222 & $* * *$ & 0.085 & $*$ \\
\hline
\end{tabular}

617

618 
619 Table 4. Trait responses to forest continuity, tree species composition and environmental variables

620 using RLQ: fourth-corner tests (Pearson correlation coefficient $r$ ) between the first two RLQ axes for

621 environmental gradients (AxisR1 and AxisR2) and plant traits. $P$ values were adjusted for multiple

622 comparisons using the FDR (false discovery rate) procedure. Codes for species traits are explained in

623 Table 2

\begin{tabular}{|c|c|c|c|c|c|}
\hline & & \multicolumn{2}{|c|}{ AxisR1 } & \multicolumn{2}{|c|}{ AxisR2 } \\
\hline & & $r$ & $P$ value & $r$ & $P$ value \\
\hline HAB.core & forest core species & -0.236 & $* * *$ & 0.020 & NS \\
\hline HAB.peripheral & peripheral species & 0.094 & NS & 0.057 & NS \\
\hline C.coord & coordinate for competition & -0.113 & $*$ & -0.018 & NS \\
\hline S.coord & coordinate for stress-tolerance & -0.148 & $* *$ & 0.064 & NS \\
\hline R.coord & coordinate for ruderality & 0.266 & $* * *$ & -0.046 & NS \\
\hline $\mathrm{pH}$ & indicator value for soil $\mathrm{pH}$ & 0.441 & $* * *$ & 0.106 & NS \\
\hline $\mathrm{N}$ & indicator value for soil nitrogen & 0.240 & $* * *$ & 0.039 & NS \\
\hline $\mathrm{L}$ & indicator value for light & 0.039 & NS & -0.096 & $* *$ \\
\hline SLA & specific leaf area & 0.225 & $* * *$ & 0.014 & NS \\
\hline LDMC & leaf dry matter content & -0.232 & $* * *$ & 0.028 & NS \\
\hline PLS.ann.bie & annual/biennial & 0.247 & $* * *$ & -0.054 & NS \\
\hline PLS.bryo & bryophyte & -0.183 & $* * *$ & 0.001 & NS \\
\hline PLS.per.herb & perennial herb & 0.157 & $* *$ & -0.026 & NS \\
\hline PLS.shr.tree & shrub/tree & -0.076 & NS & 0.044 & NS \\
\hline REPRO.s & reproduction by seed & 0.038 & NS & -0.027 & NS \\
\hline REPRO.ssv & $\begin{array}{l}\text { reproduction mostly by seed, rarely } \\
\text { vegetative }\end{array}$ & -0.058 & NS & 0.019 & NS \\
\hline REPRO.sv.vvs & reproduction by seed and vegetative & 0.158 & $* *$ & 0.020 & NS \\
\hline beg.fl & start of flowering & -0.015 & NS & -0.097 & $* *$ \\
\hline end.fl & end of flowering & 0.045 & NS & -0.124 & $* * *$ \\
\hline DISP.anemo & anemochory & -0.026 & NS & -0.122 & $* * *$ \\
\hline DISP.baro & barochory & 0.104 & $*$ & -0.053 & NS \\
\hline DISP.myrmeco & myrmecochory & 0.009 & NS & 0.083 & $* *$ \\
\hline DISP.zoo & zoochory & 0.108 & $*$ & 0.095 & $* *$ \\
\hline $\log . \mathrm{SW}$ & seed weight (log) & -0.009 & NS & 0.109 & $* *$ \\
\hline $\log . S L$ & seed length $(\log )$ & -0.107 & $*$ & 0.084 & $* *$ \\
\hline SBLI & seed bank longevity index & -0.007 & NS & -0.084 & $* *$ \\
\hline
\end{tabular}


Author-produced version of the article published in Applied Vegetation Science, 2017, 20, 468-481.

The original publication is available at http://onlinelibrary.wiley.com

DOI: 10.1111/avsc.12296

626

627

Table 5. Fourth-corner tests for bivariate associations between plant traits and environmental variables. The link is measured by a Pearson correlation coefficient for two quantitative variables (trait and environmental variable), by a Pearson $C h i^{2}$ and $G$ statistic for two qualitative variables and by a Pseudo-F and Pearson $r$ for one quantitative variable and one qualitative variable (significant associations are in bold). $P$ values were adjusted for multiple comparisons using the FDR (false discovery rate) procedure. Same legend as Tables 3 and 4.

\section{See file "Table 5.xlsx"}




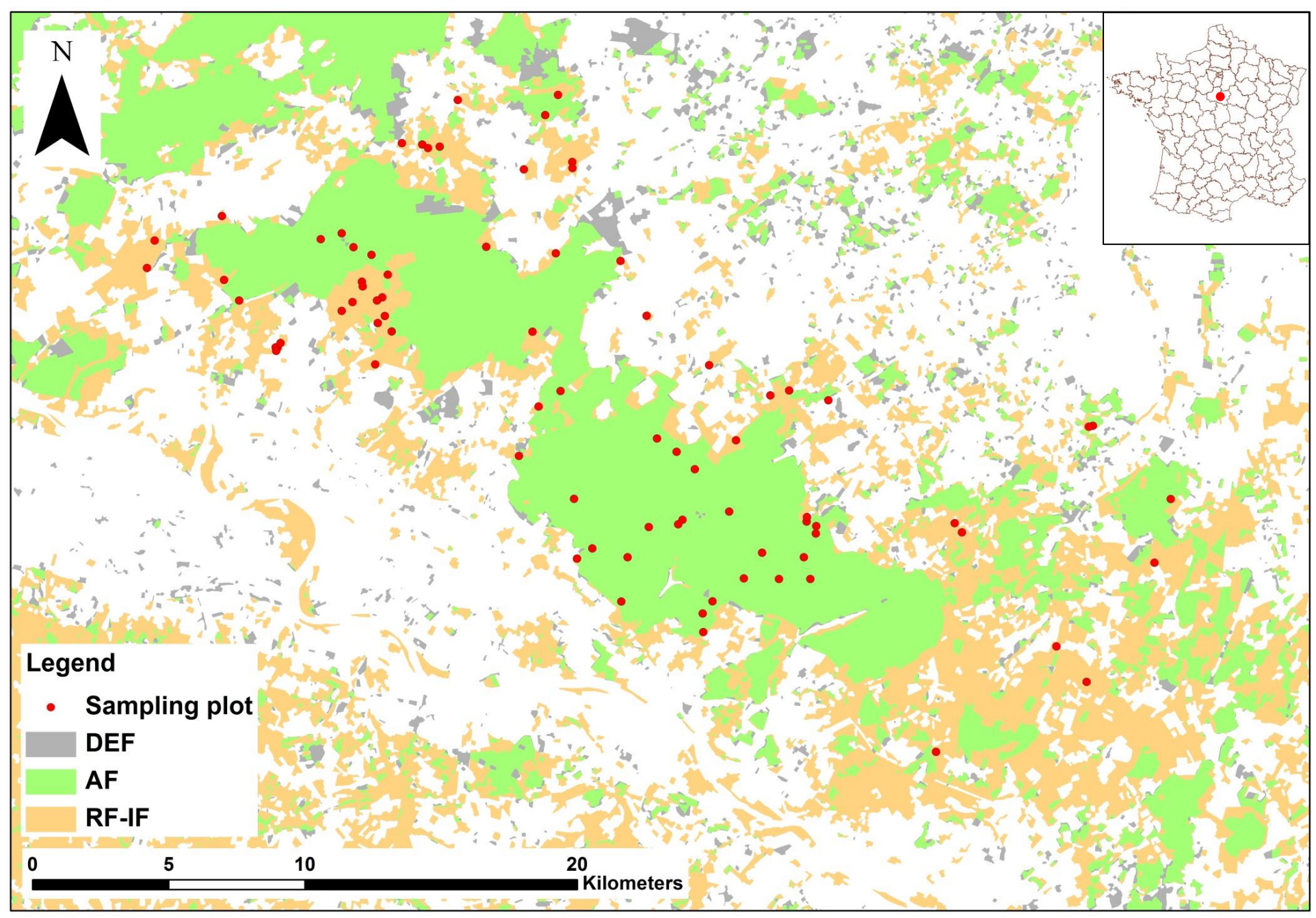

Fig. 1. Location of the 80 sampling points in the forest of Orléans (Loiret, France); AF: ancient forest (present in 1840 and 2006); RF/IF: recent or 


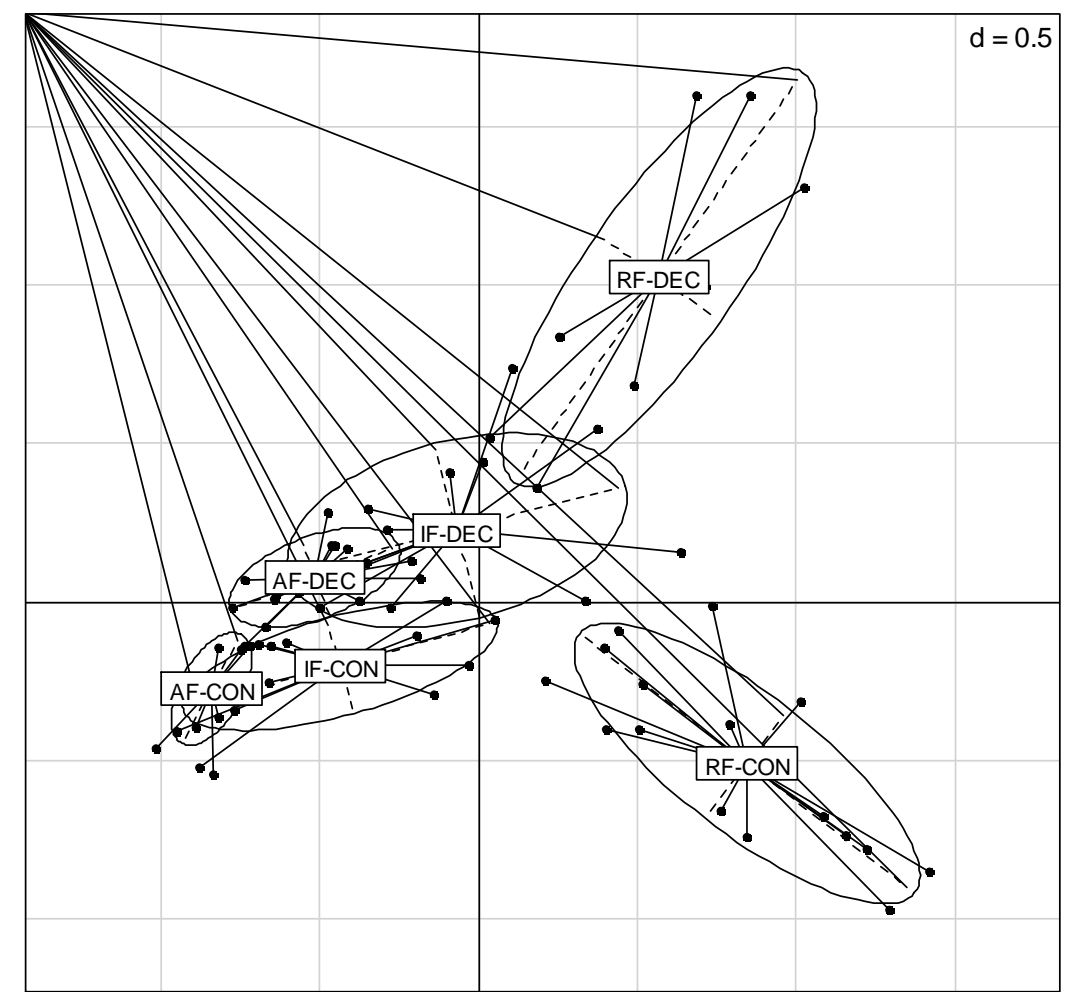

641 Fig. 2. Biplot of the sampling points in the first factorial map of the CCA applied to the matrix of 80 642 sampling sites and 197 species using forest continuity and tree species as predictors. The value of $d$ 643 gives the grid size. The plots are grouped according to stand type: AF: ancient forests; IF: intermediate644 age forests; RF: recent forests; tree species: DEC: deciduous; CON: coniferous. The ellipses comprised $64567 \%$ of the points on the hypothesis that the scatter is a simple random sample following a bivariate 646 normal distribution. 
Author-produced version of the article published in Applied Vegetation Science, 2017, 20, 468-481.

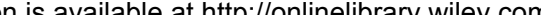

DOI: $10.1111 /$ avsc. 12296

648

(a)

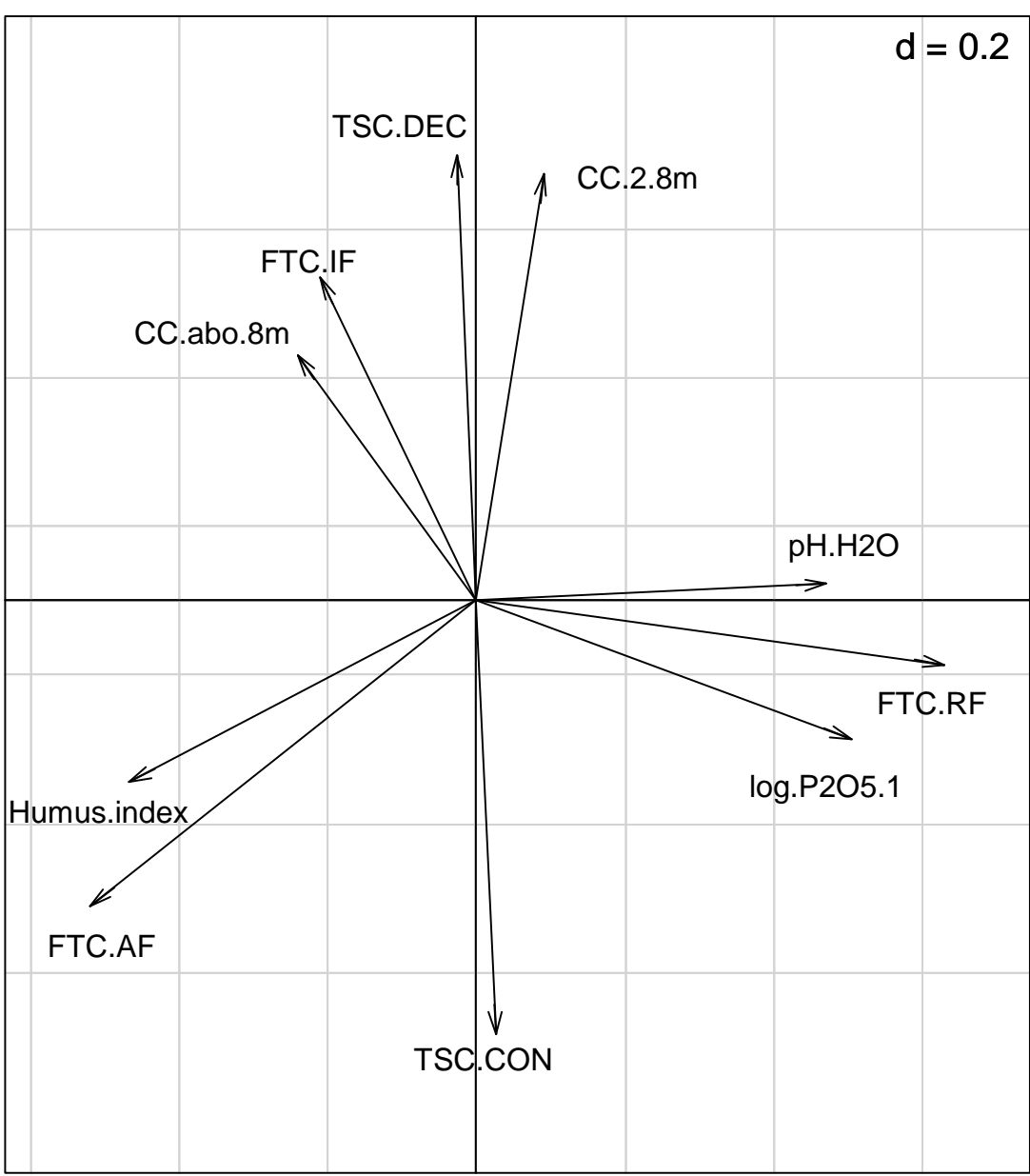

(b)

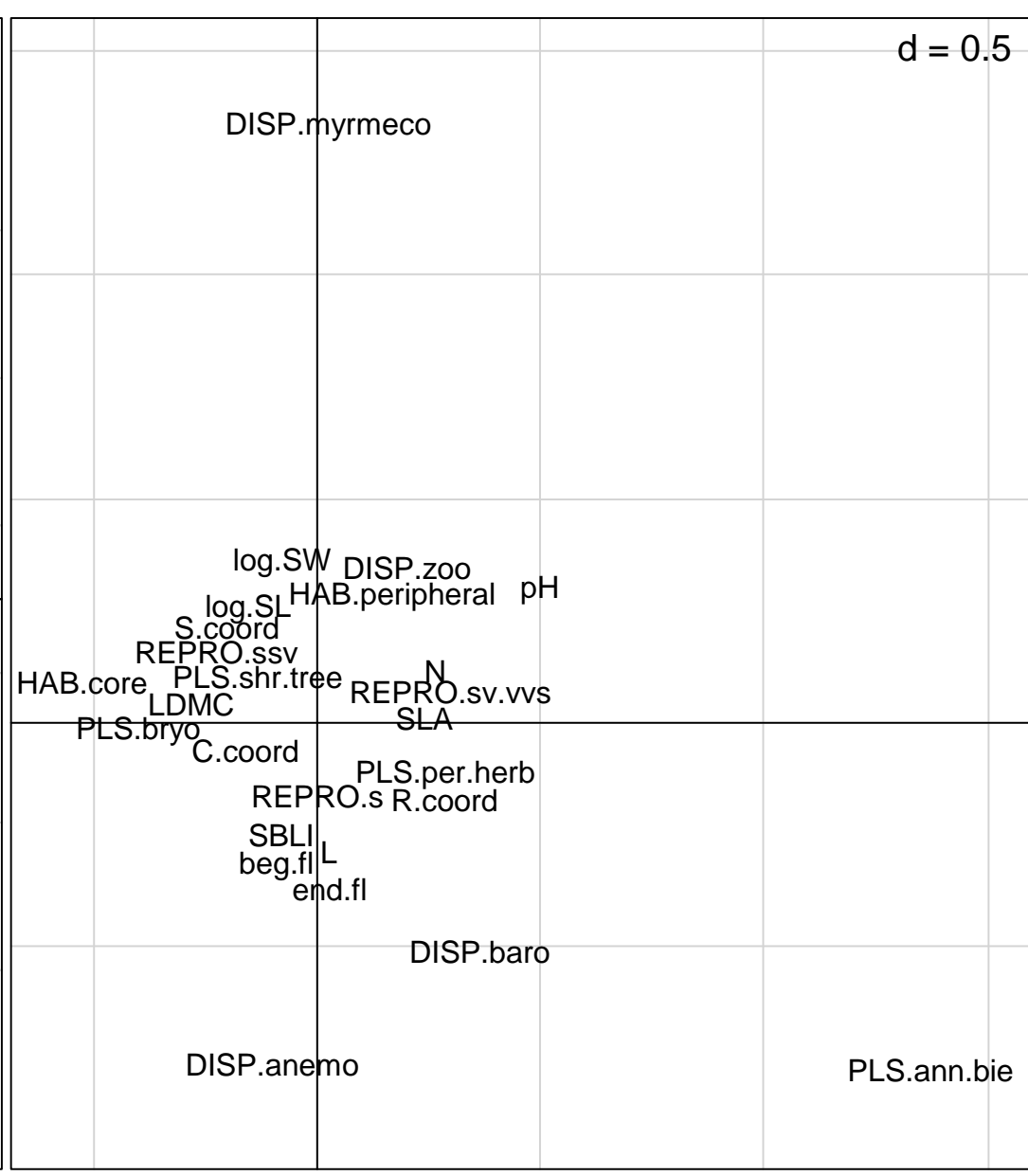

650 Fig. 3. Simultaneous ordination of (a) forest continuity, tree species and environmental variables and (b) species traits in the first RLQ factorial map. The value of $d$ gives the grid size. Codes for environmental variables: AF: ancient forest; IF: intermediate-age forest; RF: recent forest; CON: coniferous; DEC:

652 deciduous; CC >8 m: canopy cover above $8 \mathrm{~m}$; CC 2-8 m: canopy cover 2-8 m (see text and Appendix S1 for details). See Table 2 for trait category code and Appendix S6 for plant name code. 


\section{Forest core species}

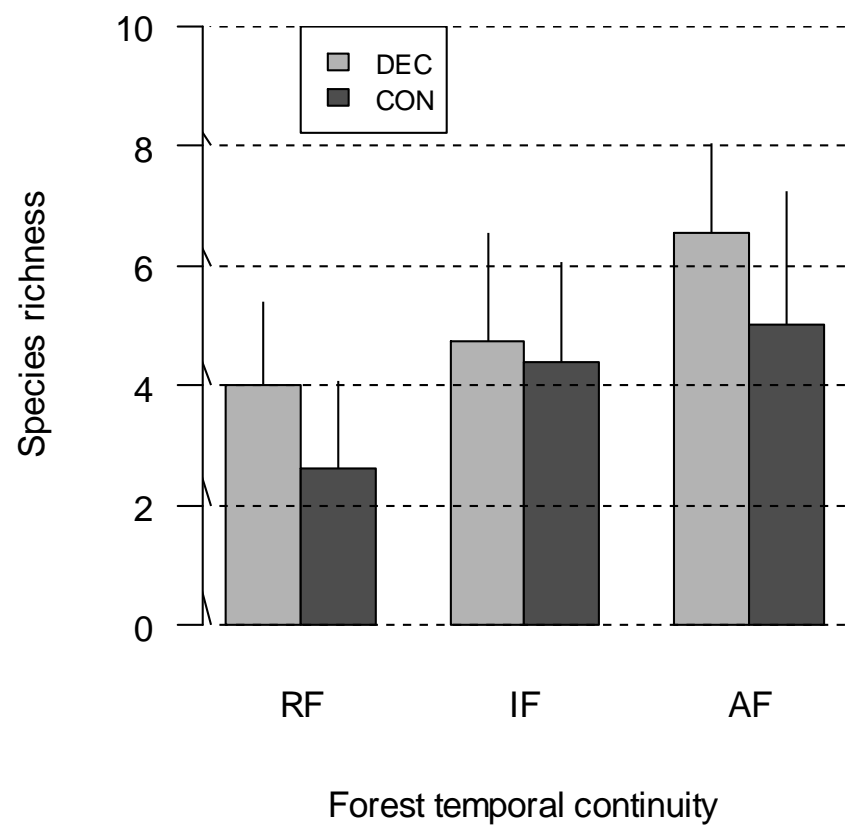

654

655 Fig. 4. Species richness of forest core plants [sensu Pellissier et al. (2013)] as a function of forest

656 continuity and tree species. The graph gives mean and standard deviation. AF: ancient forest; IF:

657 intermediate-age forest; RF: recent forest; CON: coniferous; DEC: deciduous. Model results: forest

658 continuity effect: $P<0.0001$; tree species effect: $P=0.008$; interaction: $P=0.39$; adjusted $-R^{2}=0.324$. 